\title{
Experimental evaluation of the new lance for powder injection
}

Jan Jezierski, Krzysztof Janerka

Department of Foundry, Silesian University of Technology, 7 Towarowa, 44-100 Gliwice, Poland, jan.jezierski@polsl.pl,krzysztof.janerka@polsl.pl

The paper presents the results of the evaluation experiments of the new lance for powder injection process. The pneumatic powder injection process itself has been well known since many years and it can be operated both with submerged and non-submerged lance. The new invented by authors injection lance is dedicated for processes without its submersion especially when the powders are injected into liquid metal bath inside the ladles or induction crucible furnaces. In these cases it is important to not introduce the carrier gas into metal volume to make the temperature decrease as low as possible. However, when the lance is not submerged the problem with particles jet introduction into liquid metal with proper distribution appears. The new lance of special design with slots and flange at the outlet was checked both in model water experiments and real conditions for ferroalloys injection into liquid cast grey iron. The results proved the efficiency of the powder introduction and low liquid alloy temperature decrease, too.

Keywords: powder injection, injection lance, cast iron production, alloying, induction furnace

\section{Acknowledgements}

This research project was financed from support funds for science during 2010-2013.

\section{References}

[1] SZAJNAR, J., WRÓBEL, T. (2008). Inoculation of pure aluminum with an electromagnetic field. Journal of Manufacturing Processes, Vol. 10, No. 2, pp. $74-81$.

[2] SZAJNAR, J., WRÓBEL, T. (2008). Influence of magnetic field and inoculation on size reduction in pure aluminium structure. International Journal of Materials and Product Technology, Vol. 33, No. 3, pp. 322 - 334.

[3] WRÓBEL, T. (2011). Review of inoculation methods of pure aluminium primary structure. Archives of Materials Science and Engineering, Vol. 50, No. 2, pp. 110 - 119.

[4] LIM, Y.-P. (2005). Grain refinement of LM6 Al-Si alloy sand castings to enhance mechanical properties. Journal of Materials Processing Technology, Vol 162-163, pp. 435-441.

[5] GREGER, M., WIDOMSKÁ, M. (2011). Analysis of influence of structure on mechanical properties of AlSiMg aluminium alloy processed by ECAP. Manufacturing Technology, Vol. 11, No. 11, pp. 17-22.

[6] KOVÁC, I., ŽARNOVSKÝ, J., DRLICKA, R., RUŽBARSKÝ, J. (2010). An improvement of tribological properties of boron alloyed layers. Manufacturing Technology, Vol. X, pp. 78-80.

[7] JANERKA, K., BARTOCHA, D., SZAJNAR, J., JEZIERSKI, J. (2010). The carburizer influence on the crystallization process and the microstructure of synthetic cast iron. Archives of Metallurgy and Materials, Vol. 55, No. 3, pp. $851-859$.

[8] JANERKA, K., BARTOCHA, D., JEZIERSKI, J., SZAJNAR, J. (2010). The effect of the carburiser quality on the cast iron recarburisation process. Foundry Trade Journal International, Vol. 184, No. 3679, pp. 282 - 286.

[9] SCHEEPERS, E., EKSTEEN, J.J., ALDRICH, C. (2006). Optimisation of the lance injection desulphurisation of molten iron using dynamic modeling. Minerals Engineering, Vol. 19, pp. 1163 - 1173.

[10] LIMMANEEVICHITR, C., EIDHED, W. (2003). Novel technique for grain refinement in aluminum casting by Al-Ti-B powder injection. Materials Science and Engineering, Vol. A355, pp. $174-179$.

[11] JEZIERSKI, J., JANERKA, K. (2011). Selected aspects of metallurgical and foundry furnace dust utilization. Polish Journal of Environmental Studies, Vol. 20, No. 1, pp. 101 - 105.

[12] JEZIERSKI, J., JANERKA, K. (2009). Powder pneumatic injection as a tool for wastes utilization. Archives of Materials Science and Engineering, Vol. 36, No. 2, pp. 118 - 124.

[13] JEZIERSKI, J., JANERKA, K. (2008). Pneumatic powder injection technique as a tool for waste utilization. International Journal of Environment and Waste Management, Vol. 2, No. 6, pp. 636 - 646. DOI: 10.1504/IJEWM.2008.021866.

[14] JEZIERSKI, J., SZAJNAR, J., JANERKA, K. (2010). Lanca do wdmuchiwania proszków do ciekłych stopów 
metali. Patent RP 206465 Int. Cl. F27D 3/18.

[15] JEZIERSKI, J., SZAJNAR, J. (2007). Relationship between stream forces and parameters of the powder injection into liquid metal bath. Archives of Materials Science and Engineering, Vol. 28, No. 4, pp. $238-245$.

[16] DAŃKO, J. (1992). Proces wytwarzania rdzeni i form odlewniczych metodami dmuchowymi. Badania i teoria, Zeszyty Naukowe Metalurgia i Odlewnictwo nr 145, Kraków.

[17] JEZIERSKI, J., SZAJNAR, J. (2006). Method and new lance for powder injection into liquid alloys. Journal of Achievements in Materials and Manufacturing Engineering, Vol. 17, No.1/2, pp. 349 - 352.

[18] JEZIERSKI, J., JANERKA, K. (2013). Two-phase jet in process of pneumatic powder injection into liquid alloy. Advanced Materials Research, Vols. 622-623, pp. 447-451. DOI: 10.4028/www.scientific.net/AMR.622623.447. 